\title{
HUBUNGAN MOTIVASI KEPALA SEKOLAH DAN BUDAYA SEKOLAH TERHADAP KINERJA GURU SD KECAMATAN JAWAI SELATAN
}

\author{
Purnama Sari \\ SMKN 1 Jawai Selatan, Kabupaten Sambas \\ Email: purn4m4.s4ri1984@gmail.com
}

\begin{abstract}
This research is to describe the relationship between principal's motivation and school culture on the performance of elementary school teachers in jawai selatan, Sambas. This study consisted of two independent variables and one dependent variable. They are the principal's motivation (X1) and school culture (X2) as independent variables, and teacher performance $(Y)$ as dependent variable. The subjects of this study are all elementary school teachers. This study uses a quantitative approach with a descriptive correlational design. Data collection techniques used are documentary and questionnaire techniques. The main data collection tool used is a questionnaire (questionnaire) with alternative answers in the form of a Likert scale. Technical analysis or data processing of this study using descriptive statistics and inferential statistics. The results obtained: (1) There is a relationship between the principal's motivation and teacher performance of $25.70 \%$. (2) There is a significant relationship between school culture and an increase in teacher performance of $70.13 \%$. (3) The principal's motivation and school culture have a significant relationship to the performance of teachers in the southern Jawai sub-district with a contribution of $55.70 \%$.
\end{abstract}

\section{Keywords: Motivation, School Culture, Performance of teachers}

\section{PENDAHULUAN}

Guru adalah komponen penting dari sistem pendidikan secara keseluruhan dan harus menjadi pusat mereka pertama dan terutama. Nomor tunggal ini selalu menjadi fokus strategis dalam masalah pendidikan, karena guru selalu dikaitkan dengan semua komponen sistem pendidikan.

Kinerja guru memegang peranan penting dalam perkembangan pendidikan, khususnya dalam pengembangan pendidikan formal di sekolah. Kinerja guru memiliki pengaruh yang besar terhadap keberhasilan siswa, terutama dalam kaitannya dengan proses belajar mengajar. Guru merupakan kelompok profesional yang penting dalam proses pembelajaran di sekolah. Aktivitas guru di sekolah memiliki pengaruh yang signifikan terhadap efektivitas proses belajar mengajar dan pencapaian tujuan pendidikan di sekolah.

Kinerja guru, terutama dalam proses pembelajaran di kelas, membantu siswa mengembangkan sikap positif terhadap pembelajaran, membangkitkan rasa ingin tahu, meningkatkan kemandirian dan akurasi logika intelektual, dan berhasil dalam belajar, dianggap memainkan peran penting dalam menciptakan kondisi untuk.

Guru memainkan peran yang sangat vital dalam pendidikan, menunjukkan bahwa tanggung jawab atas kualitas pendidikan berada di pundak mereka. Oleh karena itu, guru perlu berevolusi dengan meningkatkan keterampilan dan kinerjanya.

Tinggi rendahnya produktivitas dan kinerja guru di wilayah Jawai Selatan dapat dilihat dari nilai akhir siswa dan daftar absensi guru di kabupaten tersebut. Hal ini terlihat dari bagaimana kepala sekolah mengelola sekolah dan dewan guru. Salah satunya adalah motivasi direktur sekolah, yang dapat memotivasi guru untuk melatih siswanya. Motivasi kepala sekolah rendah dan kinerja guru berkurang. Guru yang tidak termotivasi adalah guru yang kurang inisiatif, kreativitas, 
dan nilai yang buruk. Selain itu, budaya sekolah yang digunakan di sekolah juga mempengaruhi kinerja guru. Kinerja guru harus didorong, dikembangkan, dimotivasi dan diakui dengan baik. Selain itu, lingkungan belajar dengan budaya sekolah yang baik mendorong guru untuk melaksanakan pekerjaannya dengan benar dan profesional.

Organisasi biasanya mengklaim dibentuk untuk mencapai tujuan tertentu melalui kinerja semua orang dalam organisasi. Namun, kinerja talenta sangat ditentukan oleh kondisi lingkungan internal dan eksternal organisasi, termasuk budaya organisasi. Oleh karena itu, diperlukan kemampuan untuk menciptakan organisasi dengan budaya yang dapat meningkatkan kinerja.

Kelangsungan hidup dan keberhasilan sekolah saat ini tergantung pada kemampuan pemimpin untuk mengantisipasi perubahan eksternal. Dalam hal ini, sekolah harus memiliki kepala sekolah yang efektif untuk menjalankan kepemimpinan dan memiliki motivasi yang tinggi untuk menjalankan tugasnya. Tantangan bagi kepala sekolah adalah menjadi promotor atau pelopor transformasi sekolah yang dijalankannya.

Keberhasilan sekolah juga sangat tergantung pada keberhasilan kepala sekolah yang mengelola staf di sekolah. Kepala sekolah bertanggung jawab atas penyelenggaraan kegiatan pendidikan, administrasi sekolah, promosi tenaga kependidikan lainnya, dan penggunaan serta pemeliharaan gedung dan prasarana. Kepala sekolah mengatakan dia memainkan peran yang sangat penting dalam menjalankan sekolah. Kepala sekolah merupakan penggerak dan penentu arah politik bagi sekolah dan pendidikan secara keseluruhan. Sebagai pimpinan lembaga, kepala sekolah berkewajiban untuk terus meningkatkan efektivitas pelayanan.

Kepala sekolah juga harus memiliki motivasi kerja yang tinggi. Hal ini merupakan salah satu faktor yang menentukan kinerja seseorang, dan besarnya dampak motivasi terhadap kinerja seseorang tergantung pada kekuatan motivasi tersebut. "Motivasi sebagai kondisi vital bagi organisasi untuk membantu membimbingnya menuju tujuan tertentu." Motivasi sebagai kondisi untuk membimbing orang ke tujuan tertentu. Oleh karena itu, keberhasilan suatu sekolah pada hakekatnya bergantung pada efisiensi dan efektivitas penampilan kepala sekolah.

Dalam hal ini kepala sekolah bertanggung jawab untuk mencapai tujuan sekolah. Kepala sekolah diharapkan menjadi pemimpin sekolah, inovator dan motivator. Oleh karena itu, kualitas kepemimpinan kepala sekolah sangat penting bagi keberhasilan sekolah.

Kepala sekolah merupakan salah satu komponen pendidikan yang berperan besar dalam meningkatkan mutu pendidikan. Kepala sekolah bertanggung jawab mengelola pendidikan yang berkaitan langsung dengan proses pembelajaran di sekolah.

"Para pemimpin sekolah dalam paradigma manajemen pendidikan baru akan memberikan dampak positif dan perubahan yang sangat besar dalam memutakhirkan sistem pendidikan sekolah." Pimpinan sekolah dituntut untuk kreatif dan produktif dalam melakukan inovasi pendidikan untuk mutu pendidikan. Mengembangkan pemimpin yang inovatif merupakan hambatan yang sulit bagi sistem kesejahteraan guru. Untuk itu peminatan manajemen sekolah pada lembaga pendidikan memerlukan berbagai upaya seperti kreativitas kerja, motivasi kerja, prestasi kerja, dan peningkatan produktivitas. Selain itu, kepala sekolah didukung oleh guru dan tenaga pendidik lainnya untuk meningkatkan mutu pendidikan.

Sekolah merupakan salah satu lembaga pendidikan yang dapat dipandang sebagai wadah pencapaian tujuan pembangunan nasional. Keberhasilan tujuan pendidikan suatu sekolah tergantung pada sumber daya yang tersedia di sekolah tersebut, antara lain kepala sekolah, guru, 
siswa, staf administrasi, dan staf sekolah lainnya.

Oleh karena itu, pandangan pendidikan yang memberdayakan kepala sekolah untuk mengembangkan metode yang berbeda perlu meningkatkan keterampilan kepala sekolah dalam berbagai cara untuk mencapai tujuan pendidikan sesuai dengan visi dan misi kepala sekolah.

Budaya sekolah, sering disebut sebagai budaya kerja, mewakili suasana hati dan hubungan kerja antara rekan guru dan kepala sekolah, antara guru dan tenaga kependidikan lainnya, dan antar departemen dalam lingkungan, serta mendukung dan efektif. lingkungan.

Menurut survei, "Organisasi budaya kuat berkinerja lebih baik daripada organisasi budaya lemah. Oleh karena itu, pemimpin yang memahami budaya perlu menggerakkan roda organisasi dan unggul. Lingkungan yang aman dan tertib, optimisme dan harapan yang tinggi dari warga sekolah, kesehatan sekolah, dan kegiatan yang berpusat pada siswa merupakan contoh budaya sekolah yang dapat merangsang kegairahan siswa. Budaya sekolah sudah menjadi kewenangan sekolah, sehingga produktivitas sekolah memerlukan upaya yang lebih fokus dan komprehensif.

Harapan yang diharapkan sesuai dengan arah kebijakan pembangunan pendidikan nasional adalah peran kepala sekolah, khususnya peran kepala sekolah sebagai motivator, yang dapat meningkatkan kinerja guru di bawah kepemimpinannya. Budaya sekolah juga diharapkan dapat menciptakan lingkungan kerja yang mendukung. Hal ini tidak tercermin di semua sekolah dasar di wilayah Jawai Selatan.

Selain itu, kemampuan guru dapat ditunjukkan melalui kinerja guru, serangkaian tindakan yang dilakukan guru ketika mengajar siswa. Salah satu bentuk kinerja guru adalah kompetensi seorang guru dalam menjalankan tugas dan tanggung jawabnya. Oleh karena itu, penilaian kinerja guru menjadi penting dan dapat dicirikan sebagai upaya untuk mengoptimalkan kesadaran keterampilan dan tanggung jawab dalam melaksanakan tugas.
Dari penjelasan tersebut dapat disimpulkan bahwa penulis tertarik untuk melakukan penelitian: "Hubungan Motivasi Kepala Sekolah dan Budaya Sekolah terhadap Kinerja Guru Sekolah Dasar Di Kecamatan Jawai Selatan Kabupaten Sambas".

\section{METODE PENELITIAN}

Penelitian ini termasuk penelitian korelasi. Penelitian ini terdiri dari dua variabel bebas dan satu variabel terikat yang berisi data tentang motivasi kepala sekolah, budaya sekolah dan kinerja guru.

Penelitian ini melibatkan guru SD berstatus PNS di Kecamatan Jawai Selatan, Kabupaten Sambas sebanyak 178 orang. Pengambilan sampel untuk penelitian ini dilakukan dengan cara random sampling. Besarnya sampel adalah 64 orang.

Metode pengumpulan data yang digunakan adalah metode dokumentasi dan metode angket. Kuesioner (pertanyaan) yang mencantumkan alternatif jawaban berupa skala likert terutama digunakan sebagai sarana penelitian. Peneliti menggunakan skala Likert karena mengukur sikap, pendapat, dan persepsi seseorang.

Teknik analisis/pengolahan data penelitian ini menggunakan statistik deskriptif dan inferensi. Statistik deskriptif digunakan untuk merepresentasikan data, dan statistik inferensi digunakan untuk menarik kesimpulan yang berlaku untuk populasi berdasarkan data sampel.

\section{HASIL PENELITIAN DAN PEMBAHASAN \\ Hasil \\ Gambaran Deskriptif}

Dari data motivasi pokok yang dikumpulkan, skor terendah adalah 84 dan skor tertinggi adalah 114. Skor rata-rata adalah 98,47 dan standar deviasi adalah 7,586 . Dalam hal ini, nilai intervalnya adalah 8. Tabel 1 menunjukkan distribusi frekuensi motivasi utama berdasarkan interval. 


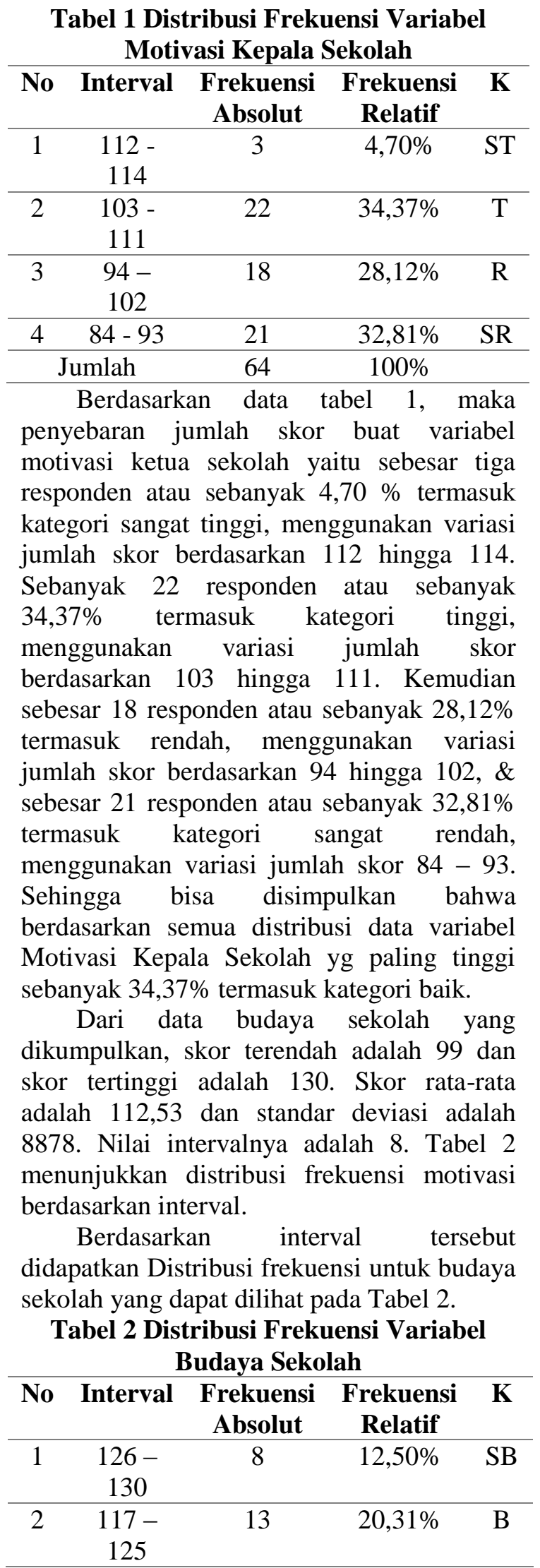

\begin{tabular}{ccccc}
\hline 3 & $\begin{array}{c}108- \\
116\end{array}$ & 22 & $34,38 \%$ & $\mathrm{CB}$ \\
\hline 4 & $99-107$ & 21 & $32,81 \%$ & $\mathrm{~KB}$ \\
\hline & Jumlah & 64 & $100 \%$ & \\
\hline & Berdasarkan & data & pada & tabel di atas,
\end{tabular}
distribusi poin total untuk budaya sekolah yang fluktuatif adalah $12,50 \%$, termasuk 8 responden atau kategori sangat baik, dengan total poin bervariasi dari 126 hingga 130 . Sebanyak 13 responden atau 20,31\% termasuk dalam kategori baik. Jumlah skor bervariasi dari 117 hingga 125. Setelah itu, sebanyak 22 responden $(34,38 \%)$ berkategori cukup baik, dengan jumlah skor berfluktuasi dari 108 menjadi 116, hingga 21 responden atau 32. $81 \%$ termasuk kategori sangat rendah dengan skor bervariasi dari 99 hingga 107. Dari seluruh sebaran data, dapat disimpulkan bahwa budaya sekolah yang paling bergejolak termasuk kategori "cukup baik" adalah 34,38\%.

Dari data yang dikumpulkan untuk variabel kinerja guru, skor terendah adalah 85 dan skor tertinggi adalah 130 . Skor ratarata adalah 110,02 dan standar deviasi adalah 11,661. Dalam hal ini, nilai intervalnya adalah 11. Tabel 3 menunjukkan distribusi frekuensi variabel kinerja guru berdasarkan interval.

Tabel 3 Distribusi Frekuensi Variabel Kinerja Guru

\begin{tabular}{|c|c|c|c|c|}
\hline No & Interval & $\begin{array}{c}\text { Frekuensi } \\
\text { Absolut }\end{array}$ & $\begin{array}{c}\text { Frekuensi } \\
\text { Relatif }\end{array}$ & $\mathbf{K}$ \\
\hline 1 & $\begin{array}{c}120- \\
130\end{array}$ & 19 & $29,68 \%$ & SM \\
\hline 2 & $\begin{array}{c}109- \\
119\end{array}$ & 14 & $21,87 \%$ & $\mathrm{M}$ \\
\hline 3 & $\begin{array}{l}97- \\
108\end{array}$ & 25 & $39,06 \%$ & $\mathrm{CM}$ \\
\hline 4 & $85-96$ & 6 & $9,40 \%$ & KM \\
\hline \multicolumn{2}{|c|}{ Jumlah } & 64 & $100 \%$ & \\
\hline
\end{tabular}

Berdasarkan data pada tabel di atas, distribusi total poin untuk variabel kinerja guru adalah 29,68\%, termasuk 19 responden, kategori sangat memuaskan, dengan poin bervariasi dari 120 hingga 130. meningkat. Sebanyak 14 responden atau 21,87\% termasuk yang merasa puas dan jumlah skor bervariasi dari 109 hingga 119. Setelah itu sebanyak 25 responden atau $39,06 \%$ 
termasuk cukup memuaskan, jumlah skor bervariasi dari 97 hingga 108, dan hingga 6 responden atau 9,40\% termasuk tidak puas. Variasi kategori dan skor 85-96.

\section{Hubungan Antar Variabel}

Uji korelasi dilakukan untuk mengetahui hubungan antara variabel penelitian dan sekaligus pembuktian hipotesis. Berdasarkan hasil uji hipotesis yang dilakukan, didapatkan hubungan motivasi kepala sekolah dan budaya sekolah terhadap kinerja guru sebagai berikut: a) Hubungan motivasi kepala sekolah (X1) dengan kinerja guru sebesar 0.257. Artinya hubungan motivasi kepala sekolah dengan kinerja guru dapat disimpulkan sebesar 25,70\%.

b) Hubungan budaya sekolah dengan kinerja guru sebesar 0.713. Artinya hubungan budaya sekolah dengan kinerja guru dapat simpulkan sebesar $70,13 \%$

c) Hubungan motivasi kepala sekolah dan budaya sekolah dari nilai $R$ Square sebesar 0.557. Hal ini menunjukkan bahwa persentase hubungan variabel independen motivasi kepala sekolah dan budaya sekolah dengan variabel dependen kinerja guru sebesar $55,70 \%$.

\section{Pembahasan}

\section{Hubungan Motivasi Sekolah terhadap Kinerja Guru}

Berdasarkan hasil penelitian yang dilakukan, kontribusi motivasional terhadap kinerja guru kepala sekolah dasar di kabupaten Jawa Selatan secara umum relatif rendah, hanya mencapai $25,70 \%$.

Motivasi kepala sekolah sangat penting untuk meningkatkan kinerja guru. Untuk menjalankan sekolahnya, mewujudkan visi dan misinya, serta mengembangkan sekolah sesuai dengan tujuan pendidikan yang diinginkan, motif bekerja harus ada dalam jiwa kepala sekolah dan tetap. Hal ini terlihat dari hasil penelitian bahwa dari seluruh sebaran data, motif utama yang berfluktuasi paling banyak masuk dalam kategori "baik" sebesar $34,37 \%$.

Hal ini sesuai dengan penelitian yang dilakukan oleh Teguh Widodowurijanto bahwa motivasi berkontribusi terhadap tingkat kinerja guru. Hal ini didukung oleh teori ERG yang dikemukakan oleh Clayton Alderfer.

Dalam motivasi kerja difokuskan pada faktor-faktor yang memicu atau memfasilitasi aktivitas individu, faktor-faktor ini berorientasi pada proses dan terkait dengan imbalan perilaku yang diterima untuk aktor, arah, tujuan, dan kinerja, termasuk kebutuhan, motivasi, dan momentum, termasuk apa yang Anda lakukan. Motivasi kerja yang lebih tinggi diharapkan dapat meningkatkan kinerja kepala sekolah dan meningkatkan kualitas sekolah.

Secara teori, banyak faktor yang mempengaruhi kinerja individu, yaiitu: lingkungan fisik sekolah, lingkungan nonfisik sekolah, dan kondisi individu. Dalam konteks kinerja guru, lingkungan fisik sekolah meliputi kondisi gedung sekolah, transportasi, letak geografis, dan sarana prasarana yang tersedia untuk melaksanakan pekerjaan tersebut.

Faktor organisasi non-fisik, di sisi lain, termasuk kepemimpinan, budaya sekolah, insentif, dan desain kerja. Kondisi individu seperti kemampuan, keterampilan, pengalaman, latar belakang pribadi dan status sosial, kecerdasan, persepsi, sikap, kepribadian dan motivasi intrinsik.

Oleh karena itu, mengingat banyaknya faktor yang mempengaruhi kinerja guru, dapat dipahami bahwa hubungan antara motivasi kepala sekolah dengan kinerja guru berada pada kategori rendah.

Motivasi untuk pekerjaan ini sangat penting dan dibutuhkan oleh manajemen sekolah untuk meningkatkan kinerjanya. Sujak Brahmasari (2008: 125) mengemukakan bahwa memahami motivasi karyawan dan lingkungan dapat membantu meningkatkan kinerja. Dalam hal ini kepala sekolah perlu memotivasi guru dengan menciptakan kondisi organisasi (iklim) dengan menciptakan budaya kerja dan organisasi serta memotivasi guru untuk bekerja lebih giat dalam mencapai hasil yang lebih baik.

Robbins (1996, p.198) mendefinisikan motivasi merupakan kesediaan dalam mengusahakan lebih tinggi menggapai tujuan 
organisasi, dikondisikan oleh kemampuan usaha ini untuk memenuhi kebutuhan individu.

Menurut Wahjosumidjo (2010, p. 50), motivasi dapat diartikan sebagai proses psikologis yang menggambarkan saling mempengaruhi antara sikap, kebutuhan, persepsi dan keputusan yang terjadi dalam diri seorang individu. Proses psikologis muncul dari faktor internal yang dikenal instrinsik.

Faktor internal seseorang dapat berupa kepribadian, sikap, pengalaman dan pendidikan atau harapan lain, aspirasi yang meluas ke masa depan, sedangkan faktor eksternal dapat disebabkan oleh berbagai faktor lain yang sangat kompleks. Namun, baik faktor motivasi eksternal dan internal muncul dari rangsangan. Dalam kehidupan organisasi, tindakan staf utamanya bertujuan. Dengan kata lain, perilaku staf biasanya ditentukan oleh keinginannya untuk mencapai tujuan dan harus selalu diamati, dipantau dan diarahkan sebagai bagian dari pelaksanaan tugas untuk mencapai tujuan organisasi.

Karakteristik individu dari berbagai jenis kebutuhan, sikap dan minat menyebabkan motif yang berbeda. Misalnya, seorang karyawan yang tertarik untuk menghasilkan uang sebanyak mungkin akan mengambil risiko lebih tinggi dan bekerja lebih keras daripada karyawan yang bermotivasi keselamatan. Karyawan yang termotivasi untuk berprestasi.

Tugas yang berbeda memerlukan persyaratan keterampilan yang berbeda, identifikasi tugas, kepentingan tugas, otonomi, dan jenis penilaian. Berbagai karakteristik yang ada pada pekerjaan tersebut memerlukan pengorganisasian dan kepegawaian yang sesuai dengan tingkat kesiapan masing-masing pegawainya. Selain itu, setiap organisasi memiliki aturan, sistem kompensasi, kebijakan, dan tugas yang berbeda yang mempengaruhi setiap karyawan. Oleh karena itu, untuk meningkatkan produktivitas yang optimal, pemimpin organisasi harus mempertimbangkan ketiga faktor tersebut dan dampaknya terhadap perilaku individu.

Hal ini sesuai dengan gagasan yang dikemukakan oleh Dirawat dalam Muladi (2010, p. 1). Di sini, kepemimpinan pendidikan digambarkan sebagai kemampuan dan proses untuk mempengaruhi, mengkoordinasikan, dan memobilisasi orang lain yang terlibat dalam kemajuan ilmu pendidikan dan praktik pendidikan. Mengajar agar kegiatan yang dilakukan dapat lebih efektif dalam mencapai tujuan pendidikan dan pelatihan.

Sebuah studi oleh Teguh (2011) menunjukkan bahwa kepemimpinan memiliki dampak positif yang signifikan terhadap kinerja perusahaan dan menyebabkan perubahan positif berupa kekuatan dinamis yang dapat mengkoordinasikan suatu organisasi untuk mencapai tujuannya.

Motivasi kerja sebagai stimulus kesenangan merupakan pendorong bagi orang untuk menjadi antusias terhadap pekerjaannya (pendidikan), memenuhi kebutuhannya, atau mencapai tujuan yang diinginkannya. Menurut Hertzberg, ada dua faktor yang mempengaruhi motivasi kerja: motivasi eksternal, motivasi eksternal. Ini termasuk pengawasan, hubungan interpersonal, insentif dan kondisi kerja. Motivasi esensial, yang berasal dari dalam diri, meliputi kemajuan karir, tanggung jawab tugas, dan dorongan untuk mencapai sesuatu (Thoha, 1983, p. 232).

Menurut Siagian (2004, p. 294), faktorfaktor yang mempengaruhi motivasi dapat dibedakan menjadi dua faktor yaitu motivasi internal dan motivasi eksternal. Faktor motivasi internal meliputi (1) kesadaran diri, (2) harga diri, (3) harapan pribadi, (4) kebutuhan, (5) keinginan, (6) kepuasan kerja, dan (7) pekerjaan. Faktor motivasi eksternal meliputi (1) sifat dan sifat pekerjaan, (2) kelompok kerja di mana orang berpartisipasi, (3) organisasi tempat mereka bekerja, (4) kondisi lingkungan umum, dan (5) diseminasi. dan bagaimana menerapkannya.

Oleh karena itu, kepala sekolah harus memiliki motivasi karena ia adalah seorang 
profesional organisasi sekolah yang bertanggung jawab untuk mengelola semua sumber daya organisasi dan bekerja sama dengan guru untuk mendidik siswa untuk mencapai tujuan pendidikannya. Di bawah bimbingan kepala sekolah, pengembangan profesional tenaga kependidikan mudah dikelola, dan kepala sekolah memahami kebutuhan sekolah yang dijalankannya, tergantung perannya, sehingga meningkatkan kemampuan dan kinerja guru serta meningkatkan kualitas pembelajaran.

Pencapaian tujuan pendidikan sangat bergantung pada keterampilan kepemimpinan dan kearifan salah satu pemimpin pendidikan yaitu kepala sekolah. Kepala sekolah adalah spesialis dalam organisasi sekolah yang bertanggung jawab untuk mengelola semua sumber daya organisasi dan bekerja sama dengan guru untuk mendidik siswa dan mencapai tujuan pendidikan mereka.

Menurut Wahjosumidjo (2010, p. 97), kewajiban kepala sekolah adalah: Pertama, kepala sekolah bekerja dengan dan melalui orang lain. Kepala sekolah berperan sebagai penghubung di lingkungan sekolah. Kepala sekolah bertindak dan bertanggung jawab terhadap segala tindakan organisasi dibawanya.

\section{Hubungan Budaya Sekolah terhadap Kinerja Guru}

Berdasarkan hasil penelitian, uji hipotesis beta $0,713=70,13 \%$ (b1) menunjukkan hubungan positif antara budaya sekolah dengan kinerja guru, sehingga sebenarnya antara budaya sekolah dan kinerja guru terbukti memiliki hubungan yang signifikan. Dari 70, 13\% menilainya sebagai baik.

Budaya sekolah sangat vital dalam meningkatkan kinerja guru. Budaya sekolah sangat penting karena jiwa (semangat) sekolahlah yang memberi makna terhadap kegiatan pendidikan sekolah.

Hal ini sesuai dengan penelitian Wibowo (2010, p.6): "Organisasi dengan budaya kuat berkinerja lebih baik daripada organisasi dengan budaya lemah. Oleh karena itu, pemimpin yang memahami budaya adalah organisasi. Anda perlu menggerakkan roda dan unggul.

Sekolah harus mampu menciptakan budaya sekolahnya sendiri, baik sebagai identitas diri maupun sebagai kebanggaan sekolah. Pentingnya membangun budaya sekolah terutama dalam hal upaya pencapaian tujuan pendidikan sekolah dan peningkatan kinerja sekolah.

Hal ini sesuai dengan penelitian yang dilakukan oleh Ori Pumpkin yang menyatakan bahwa "besarnya kontribusi efektif berasal dari faktor atau variabel lain".

Budaya organisasi dibentuk oleh seluruh anggota organisasi yang memperhatikan etika, aturan bisnis dan jenis struktur organisasi. Budaya organisasi membentuk dan mengatur perilaku organisasi dan anggotanya melalui struktur organisasi. (Hadari Nawawi, 2006).

Menurut Uhar Suharsaputra (2011), budaya organisasi adalah suatu bentuk kontrol sosial yang mengakar yang mempengaruhi karyawan/anggota suatu organisasi dalam pengambilan keputusan dan perilaku.

Oleh karena itu, budaya sekolah sebagai suatu organisasi yang memuat norma dan nilai dasar kehidupan manusia sangat besar pengaruhnya terhadap pembentukan perilaku kepala sekolah dan guru dalam melaksanakan dan menunjang kegiatan sesuai fungsinya masing-masing, mereka mencapai nilai dan pentingnya pekerjaan yang dilakukan di sekolah. Dan tentu saja, prestasi kepala sekolah dan guru SD di wilayah Jawai Selatan dapat ditelusuri kembali ke kontribusi organisasi dan budaya mereka.

Hubungan Motivasi Kepala Sekolah, Budaya Sekolah dengan Kinerja Guru

Dari hasil uji hipotesis dapat diketahui bahwa motivasi kepala sekolah dan budaya sekolah berkorelasi signifikan dengan kinerja guru dengan kontribusi sebesar 55,70\%. Hal ini menunjukkan bahwa terdapat 44,30\% faktor pendukung lain yang mempengaruhi kinerja guru, antara lain faktor pembinaan, lingkungan sekolah, iklim sekolah, kepemimpinan dan kondisi sosial ekonomi. 
Selanjutnya dari faktor guru itu sendiri seperti produktivitas kerja dan disiplin.

Kemudian, masih ada salah satu kendala dalam meningkatkan kinerja guru: sarana dan pra sarana sekolah, terutama yang mendukung kegiatan pendidikan dan pembelajaran guru. Keterbatasan kemampuan finansial, peralatan laboratorium, kelengkapan media pembelajaran dan perpustakaan, serta ruang kelas yang baik untuk menunjang pembelajaran masih kurang.

Terakhir, faktor lingkungan seperti alam, masyarakat, budaya dan politik juga mempengaruhi kelangsungan proses pembelajaran. Lingkungan belajar yang aman, tertib dan nyaman menjamin proses belajar yang aman dan nyaman.

Secara umum faktor fisik dan non fisik memiliki pengaruh yang signifikan. Berbagai kondisi lingkungan fisik sangat berpengaruh terhadap kondisi kerja karyawan. Selain itu, keadaan lingkungan fisik mempengaruhi berfungsinya faktor lingkungan non fisik.

Robert L. Mathias dan John H dari Khaerul Umam. Menurut Jackson (2010, p.189), ada lima faktor yang mempengaruhi kinerja individu. Yaitu, kemampuan, motivasi, dukungan yang diterima, keberadaan pekerjaan yang mereka lakukan, dan pengorganisasian orang-orangnya.

Berdasarkan pengertian di atas, Khaerul Umam (2010, p.189) menarik kesimpulan sebagai berikut. Prestasi adalah kualitas dan kuantitas kerja (hasil) seorang individu atau kelompok dalam suatu kegiatan tertentu, yang dicapai dengan kemampuan atau kemampuan alami yang muncul dari proses belajar. Dan keinginan dimulai dan penyebabnya berakhir

Mangkunergara dari Kherul Umam (2010, p.189) menyatakan bahwa faktorfaktor yang mempengaruhi kinerja antara lain: a) Faktor kemampuan. Secara psikologis, kemampuan pegawai terdiri dari potensi (IQ) dan realisme (pendidikan). Oleh karena itu, karyawan harus mendapatkan pekerjaan yang sesuai dengan keahliannya. b) Faktor motivasi. Unsur ini terbentuk dari sikap karyawan dalam menghadapi situasi kerja. Motivasi adalah suatu kondisi yang memotivasi karyawan untuk mencapai tujuan kerjanya. c) Sikap adalah sikap yang mendorong seseorang untuk mencapai potensi kerja yang maksimal.

Berdasarkan penjelasan di atas, penulis menyimpulkan bahwa kinerja guru dipengaruhi oleh faktor internal dan eksternal guru. Faktor internal adalah kelompok variabel individu dan kelompok variabel psikologis, sedangkan faktor eksternal guru adalah kelompok variabel organisasi, lingkungan fisik dan non fisik organisasi.

Namun dari semua faktor yang mempengaruhi kinerja guru, dua faktor yang diteliti berdasarkan survei yaitu motivasi kepala sekolah dan budaya sekolah berpengaruh terhadap kualitas efektivitas pembelajaran di sekolah yang bekerja secara sinergis dalam upaya peningkatan kinerja.

Dengan kata lain, melalui motivasi inti yang tinggi dan budaya sekolah yang baik, guru diharapkan lebih mengalami perubahan perilaku, sikap dan pengetahuan, baik secara individu maupun kelompok, serta meningkatkan kinerja guru.

\section{SIMPULAN DAN SARAN \\ Simpulan}

Berdasarkan penelitian, diperoleh kesimpulan: (1) Hubungan antara motivasi kepala sekolah dengan kinerja guru relatif rendah, hanya mencapai $25,70 \%$. (2) Terdapat hubungan yang signifikan antara budaya sekolah dengan peningkatan kinerja guru sebesar 70,13\%. (3) Dengan kontribusi sebesar 55,70\%, motivasi kepala sekolah dan budaya sekolah sangat berkaitan dengan kinerja guru.

\section{Saran}

Guna meningkatkan kualitas proses pembelajaran di sekolah, guru diharapkan dapat terus meningkatkan motivasi dan kinerjanya serta menjadi guru yang memiliki kompetensi dan keahlian yang tinggi dalam melaksanakan tugasnya. Peneliti lain kemudian diharapkan dapat mengeksplorasi faktor-faktor yang mempengaruhi kinerja guru, baik dari segi variabel yang dipelajari maupun kerangka teorinya, untuk 
menemukan solusi masalah kualitas guru dengan berbagai sarana pendukung.

\section{DAFTAR RUJUKAN}

Deni, K., Halimah. (2008). Seluk Beluk Profesi Guru. Bandung: PT. Pribumi Mekar.

Mulyadi. (2010). Kepemimpinan Kepala Sekolah dalam Mengembangkan Budaya Mutu. Malang: UIN Maliki Press.

Mulyasa, E. (2006). Menjadi Kepala Sekolah Profesional. Bandung: PT Remaja Rosdakarya.

Nawawi, H. (2006). Kepemimpinan Mengefektifkan Organisasi. Yogyakarta: Gajah Mada university Presss.

Ori, L. (2008). Hubungan Gaya Kepemimpinan Kepala Sekolah, Budaya Sekolah, dan Motivasi Kerja Dengan Kinerja Guru pada SMP Negeri di Kabupaten Sumba Barat. Malang: Program Pascasarjana Universitas Negeri Malang.

Robbins P. S, (1996). Perilaku Organisasi, Edisi Bahasa Indonesia. Jakarta: Prehallindo.
Uhar, S. (2010). Administrasi Pendidikan. Bandung: Refika Aditama.

Sulthon M. (2009). Membangun Semangat Kerja Guru. Yogyakarta: LaksBang PRESSindo.

Miftah, T. (2010). Kepemimpinan dalam Manajemen. Jakarta: Rajawali Pers

Teguh. (2011). Hubungan Peran Kepemimpinan Kepala,Budaya Sekolah Dan Motivasi Kerja Guru Dengan Kinerj a Guru Smk Negeri Se Kabupaten Bojonegoro. Malang : Program Pascasarjana Universitas Negeri Malang.

Khaerul, U. (2010). Perilaku Organisasi. Bandung: CV. Pustaka Setia.

Wahjusumidjo. (2010). Kepemimpinan Kepala Sekolah. Tinjauan Teoritik dan Permasalahannya. Jakarta: PT. Raja Grafindo Persada.

Wibowo. (2010). Budaya Organisasi. Sebuah Kebutuhan untuk Meningkatkan Kinerja Jangka Panjang. Jakarta. PT. Raja Grafindo Persada.

Martinis, Y., Maisah (2010). Standarisasi Kinerja Guru. Jakarta: Gaung Persada. 